\title{
Scientific note: molecular detection of pathogens in unhealthy colonies of Apis mellifera jemenitica
}

\author{
Nizar Haddad ${ }^{1}$, Moath Al-GHaraibeH ${ }^{1}$, Abdullah NASHER ${ }^{2}$, Eman AnASWAH ${ }^{1}$, \\ Yaseen Alammari $^{3}$, Lisa Horth ${ }^{4}$ \\ ${ }^{1}$ Bee Research Department, National Center for Agricultural Research and Technology Transfer, Baqa' 19381, Jordan \\ ${ }^{2}$ Department of Plant Protection, Sana'a University, Sana'a, Yemen \\ ${ }^{3}$ Beekeeping Unit - IFAD Project, Al Dhala, Yemen \\ ${ }^{4}$ Department of Biological Science, Old Dominion University, Norfolk, VA 23529, USA
}

Received 25 May 2017 - Revised 12 June 2017 - Accepted 4 July 2017

bee disease / bee virus / colony collapse disorder / deformed wing virus / Nosema / Varroa

Little is known about the honey bees (Apis mellifera) found across the Middle East and North Africa (MENA). This is true, despite the economic value of beekeeping in the region, and the particularly high value of sidr honey, which comes from the Arabian Peninsula (Alqarni et al. 2011). Regionally, beekeepers report abnormally high rates of honeybee mortality and disappearance of colonies here (Haddad 2011), yet scant data addresses bee pathogens and disease. Nearly all bee disease research in MENA involves the subspecies Apis mellifera intermissa (Adjlane et al. 2012a, b; Belaid and Et Doumandji 2010; El-Niweiri and El-Sarrag 2006; El-Niweiri et al. 2008; Haddad 2014; Haddad et al. 2015; Ellis and Munn 2005). However, Apis mellifera jemenitica is another important subspecies, with a native range that extends from Senegal to the Arabian Peninsula. A.m. jemenitica is valued for beekeeping (Ruttner 1975; Al-Ghamdi et al. 2013) yet no data exists on pathogen prevalence for this subspecies. Nor is there molecular disease data for bees in Yemen, where the major agricultural reference (Agricultural Statistical Book 2012) lists

Corresponding author: L. Horth, lhorth@odu.edu Manuscript editor: Peter Rosenkranz honeybee "pests and diseases" merely as wax moths, hornets, bee wolves, bee-eaters, and varroa mites.

This work evaluates pathogen prevalence in A. m. jemenitica in Yemen. Honey bees were collected at 16 sites ( $\sim 50$ workers/site) in nine beekeeping regions of Yemen (Figure 1). Individual bees were randomly collected from inside colonies exhibiting signs of disease, including deformed wings, hairlessness, crawling around the hive entrance, and reduced colony size. Collected bees were immediately preserved in ethanol (Evans et al. 2013), shipped to Jordan, removed from ethanol, then stored at $-80^{\circ} \mathrm{C}$.

\section{RNA EXTRACTION AND RT-PCR}

For RT-PCR analysis, five to seven bees were randomly selected from each collection, then homogenized with $1 \mathrm{~mL}$ Trizol (Biobasic) using new, alcohol-disinfected, autoclave-sterilized mortar and pestles. Homogenate was transferred to $1.5 \mathrm{~mL}$ microfuge tubes. The protein fraction was separated out in the organic fraction with chloroform, and the RNA was precipitated from the aqueous phase with $1 \mathrm{~mL}$ of isopropanol and 


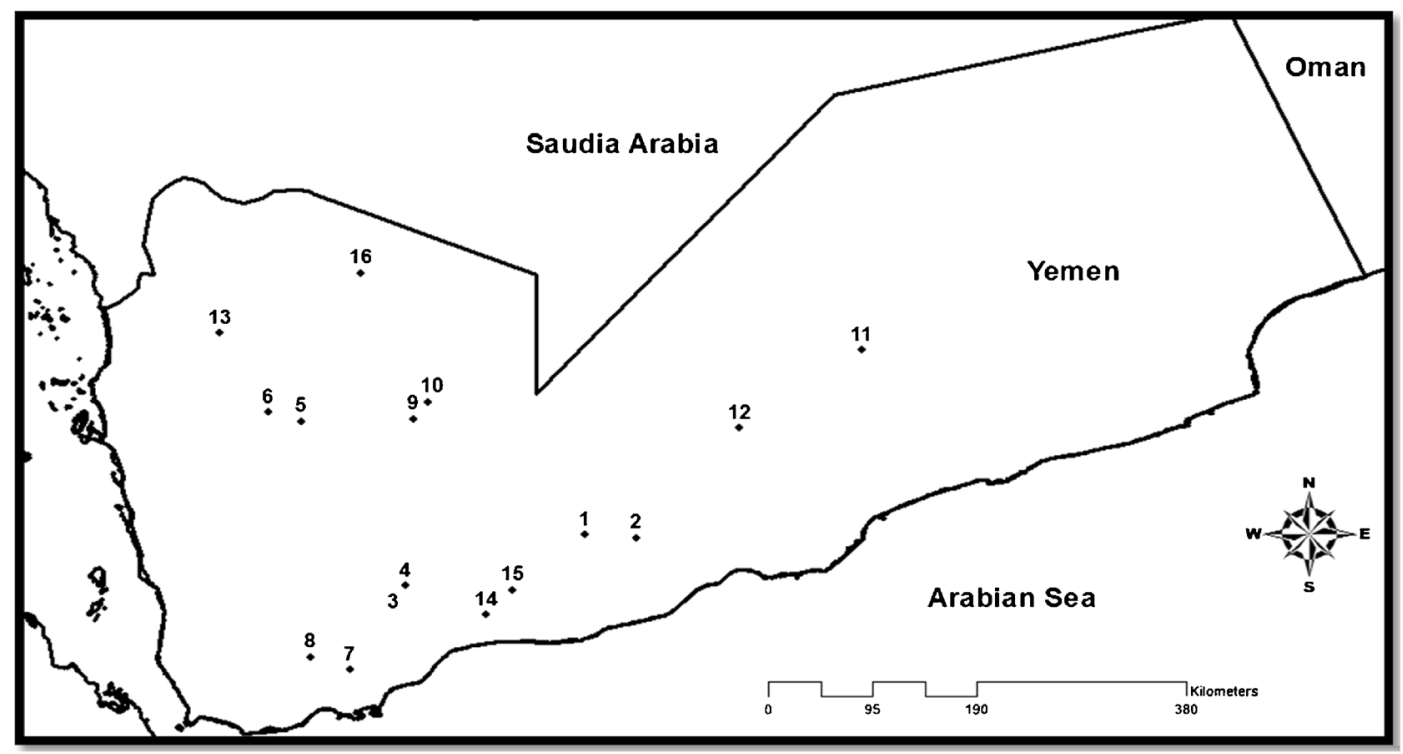

Figure 1. A map with the location of the 16 geographic sites sampled across Yemen for the presence of viral disease and Nosema in honeybee colonies that appeared sick. Site 1 and 2 are located in Shabwa, 3 and 4 in Addali, 5 and 6 in Sana'a, 7 and 8 in Lahj, 9 and 10 in Marib, 11 and 12 in Hadramaut, 13 in Amran, 14 and 15 in Ibian, and 16 in Al jawf.

centrifugation at 14,000rpm. The resultant nucleic acid pellets were washed two times with $70 \%$ ethanol and then resuspended in nuclease-free water. Each RNA sample of homogenized material per colony was analyzed for the presence of bee viral sequences using the Access RT-PCR system (Promega, USA) according to the company protocol. Amplification occurred in a $25-\mu \mathrm{L}$ reaction mixture containing $1 \mathrm{X}$ reaction buffer, $0.2 \mathrm{mM}$ dNTP, $1 \mu \mathrm{M}$ each of the forward and reverse primers for each viral sequence, $2 \mathrm{mM}$ $\mathrm{MgSO} 4,0.1 \mathrm{U}$ of avian myeloblastosis virus reverse transcriptase, $0.1 \mathrm{U}$ of' Tfl DNA polymerase, and 250 to $500 \mathrm{ng}$ of total RNA. Reverse transcription occurred at $48^{\circ} \mathrm{C}$ for $48 \mathrm{~min}$ and was followed by 40 cycles of $95^{\circ} \mathrm{C}$ for $30 \mathrm{~s}, 55^{\circ} \mathrm{C}$ for $1 \mathrm{~min}, 68^{\circ} \mathrm{C}$ for $2 \mathrm{~min}$, and a final extension at $68{ }^{\circ} \mathrm{C}$ for $7 \mathrm{~min}$. Positive and negative controls were included in each RT-PCR experimental run. Ten microliters of amplified product was electrophoresed in a $2 \%$ agarose gel and stained with ethidium bromide. Bands were photographed under UV light. A 100-bp reference ladder (Promega) was used to estimate fragment sizes.

Bees were assayed via reverse transcription polymerase chain reaction for deformed wing virus (DWV), Israeli acute paralysis virus (IAPV), chronic bee paralysis virus (CBPV), slow bee paralysis virus (SBPV), Kashmir bee virus (KBV), acute bee paralysis virus (ABPV), Sacbrood virus (SBV), Varroa destructor virus-1 (VDV-1), and via polymerase chain reaction for two microsporidian species, Nosema cerana and $N$. apis using previously published primers.

\section{DNA EXTRACTION AND PCR AMPLIFICATION}

For microsporidian PCR work, DNA was extracted from $\sim 45$ bees per collection with Nucleospin extraction kits (Macherey-Nagel). DNA was suspended in $100 \mu \mathrm{L}$ of $5 \mathrm{mM}$ Tris and stored at $-80^{\circ} \mathrm{C}$. PCR for rRNA genes of $N$. ceranae and $N$. apis was conducted using previously published primers. $50-80 \mathrm{ng} / \mathrm{uL}$ DNA was used per reaction. PCR protocol was denaturation at $95^{\circ} \mathrm{C}$ for $2 \mathrm{~min}, 35$ cycles of $95^{\circ} \mathrm{C}$ for $20 \mathrm{~s}, 56^{\circ} \mathrm{C}$ for $20 \mathrm{~s}$, and $72{ }^{\circ} \mathrm{C}$ for $30 \mathrm{~s}$, with a final extension at $72{ }^{\circ} \mathrm{C}$ for $5 \mathrm{~min}$. Products were analyzed on $1 \%$ agarose gels with reference ladders, stained with ethidium bromide and visualized under UV light. 


\section{RESULTS}

We found honeybee pathogens and disease to be widespread in Yemen. High levels of varroa mites were found at all hives assayed. Most sites ( $n=10 / 16)$ tested positive for at least one virus (Table I), with infection broadly distributed geographically (Figure 1).

The south central region of Yemen, Shabwa (sites 1 and 2, Figure 1) tested positive for three viruses (DWV, ABPV, and IAPV) plus $N$. ceranae. However, northeast of Shabwa, $\sim 200+\mathrm{km}$, in Hadramaut, no viruses or Nosema sp. were detected. Yet, southwest of Shabwah, $\sim 200 \mathrm{~km}$, Ibian (sites 14, 15) tested positive for two different viruses (VDV, KBV) plus $N$. apis. West of Ibian $\sim 100 \mathrm{~km}$, in Addali (sites 3, 4) no pathogens were detected. Southwest of Addali, $100 \mathrm{~km}$ away in Lahj (sites 7, 8), only $N$. apis was detected.

Moving to the northwestern section of Yemen, due north of Lahj $\sim 200 \mathrm{~km}$, Sana'a (sites 5, 6) tested positive for two viruses (DWV, KBV) and both Nosema sp. To the east of Sana'a $\sim 150 \mathrm{~km}$, in Marib (sites 9, 10), one virus (DWV) and both
Nosema sp. were present. Further north of Marib, another $\sim 100 \mathrm{~km}$, in $\mathrm{Al}$ jawf (site 16), one virus (DWV) and N. apis were detected. West and slightly south of Al jawf $\sim 100 \mathrm{~km}$, in Amran (site 13), one virus (KBV) and $N$. apis were detected.

In sum, DWV was present at 6/16 sites, KBV at 5/16 sites, ABPV at 2/15 sites, and IAPV and VDV at $1 / 16$ sites each. No sites demonstrated evidence of infection with CBPV, SBPV or SBV. Nosema was also widespread at 10/16 sites. $N$. apis was detected at 7/16 sites and was more common than $N$. cerana, which was detected at 3/16 sites. Two sites tested positive for both Nosema species. There was one case of $N$. cerana in the absence of $N$. apis, and five cases of $N$. apis found in the absence of $N$. cerana. On average, colonies testing positive for infection had 2.27 pathogenic species present. Most sites differed from one another in total pathogen complement, however $N$. apis plus either DWV or KBV were the parasites found together most often.

This work shows that $A$. m. jemenitica demonstrates various pathogenic infections throughout much of Yemen, but not in Hadramaut, an

Table I. Presence (+) and absence (-) results of RT-PCR assays for eight honey bee viruses and PCR assays for two Nosema species in 16 total samples from nine beekeeping regions in Yemen. All colonies presented with varroa mites and exhibited signs of disease

\begin{tabular}{lllllllllll}
\hline Region (site \#) & DWV & IAPV & CBV & SBPV & KBV & ABPV & SBV & VDV & N. cer. & N. apis \\
\hline Shabwa (1) & + & - & - & - & - & + & - & - & + & - \\
Shabwa (2) & + & + & - & - & - & + & - & - & - & - \\
Addali (3) & - & - & - & - & - & - & - & - & - & - \\
Addali (4) & - & - & - & - & - & - & - & - & - & - \\
Sana'a (5) & - & - & - & - & + & - & - & - & - & + \\
Sana'a (6) & + & - & - & - & + & - & - & - & + & + \\
Lahj (7) & - & - & - & - & - & - & - & - & - & - \\
Lahj (8) & - & - & - & - & - & - & - & - & - & + \\
Marib (9) & + & - & - & - & - & - & - & - & + & + \\
Marib (10) & + & - & - & - & - & - & - & - & - & - \\
Hadramaut (11) & - & - & - & - & - & - & - & - & - & - \\
Hadramaut (12) & - & - & - & - & - & - & - & - & - & - \\
Amran (13) & - & - & - & - & + & - & - & - & - & + \\
Ibian (14) & - & - & - & - & + & - & - & + & - & - \\
Ibian (15) & - & - & - & - & + & - & - & - & - & + \\
Al jawf(16) & + & - & - & - & - & - & - & - & - & + \\
\hline
\end{tabular}


important region for the production of sidr honey. Our work complements the only other study (Allen and Ball 1996) that, to our knowledge, assesses viruses in MENA. That work occurred in a different part of MENA (Saudi Arabia), and involved different (serological) methods. In Saudi Arabia, A. m. jementica shows signs of disease, but until now mites (Varroa jacobsoni) and bee lice (Braula coeca) were considered the most abundant parasites in apiaries (Al-Ghamdi et al. 2013). Recently, Apis mellifera carnica was imported into Saudi Arabia, largely from Egypt (Ali 2011) which could expose A. m. jemenitica to novel parasites. Other subspecies have also shown molecular evidence of infection in this major geographic region, including in Jordan (Haddad et al. 2008), United Arab Emirates (Berenyi et al. 2007), and Algeria (Loucif-Ayad et al. 2013). Further work is clearly warranted on pathogenic disease in honey bee subspecies across MENA, as well as on the impact of migration of subspecies upon one another, and the likelihood for transmission of disease when this occurs.

\section{ACKNOWLEDGMENTS}

We thank USAID (project number M29-075) for funding the laboratory experiments and USAID-CLPYemen project for facilitation of sample collection in Yemen and transfer to Jordan.

Contributions LH wrote ms NH et al. conducted molecular work and collection of samples.

Note scientifique: détection moléculaire de pathogènes dans des colonies malades d'Apis mellifera jemenitica

Eine wissenschaftliche Notiz zum molekularen Nachweis von Pathogenen in symptomatischen Bienenvölkern von Apis mellifera jemenitica

\section{REFERENCES}

Adjlane, N., Doumandji, S.E., Haddad, N. (2012a) Situation de l'apiculture en Algérie: facteurs menaçant la survie des colonies d'abeilles locales Apis mellifera intermissa. Cahiers Agric., 21, 235-41.
Adjlane, N., Kechih, S., Doumandji, S.E., Haddad, N. (2012b) Survey of American foulbrood in Apis mellifera intermissa colonies in mid-northern region of Algeria. Uludag Bee J. 12, 98-105.

Agricultural Statistical Book (2012) Ministry of Agriculture and Irrigation, General Directorate of Agricultural Statistics Republic of Yemen, 46-49

Al-Ghamdi, A., Nuru, A., Khanbash, M.S., Smith, D.R. (2013) Geographical distribution and population variation of Apis mellifera jementica Ruttner. J. Agric. Res. 52(3), 124-133.

Ali, M.A.M. (2011) Comparative study for evaluating two honey bee races, Apis mellifera jementica (indigenous race) and Apis mellifera carnica (carniolan race) in brood production, population development and foraging activity under the environmental conditions of the central region of the Kingdom of Saudi Arabia. Ann. Agric. Sci., 56 (2), 127-134.

Allen, M.F., Ball, B.V. (1996) The incidence and world distribution of honey bee viruses. Bee World, 77, 141-162.

Alqarni, A.A., Hannan, M.A, Owayss, A.A., Abdulaziz, M.S., Engel, A. (2011) The indigenous honey bees of Saudi Arabia (Hymenoptera, Apidae, Apis mellifera jemenitica Ruttner): their natural history and role in beekeeping. Zookeys, 134, 83-98.

Belaid, M., Et Doumandji, S. (2010) Effet du Varroa destructor sur la morphométrie alaire et sur les composants du système immunitaire de l'abeille ouvrière Apis mellifera intermissa. Lebanese Sci. J., 11, 45-53.

Berenyi, O., Bakonyi, T., Derakhshifar, I., Köglberger, H., Topolska, G., Ritter, W. et al. (2007) Phylogenetic analysis of deformed wing virus genotypes from diverse geographic origins indicates recent global distribution of the virus. Appl. Environ. Microbiol., 73, 3605-3611.

Ellis, J.D., Munn, P.A. (2005) The worldwide health status of honey bees. Bee World 86, 88-101.

El-Niweiri, M.A.A., El-Sarrag, M.S.A. (2006) Detection of the parasitic mite (Varroa jacobsoni) of honeybees Apis mellifera in Sudan. Albuhuth, 10(1), 60-75.

El-Niweiri, M.A.A., El-Sarrag, M.S.A., Satti, A.A. (2008) Survey of diseases and parasites of honey bees (Apis mellifera L.) in Sudan. Sudan J. Basic Sci., 14, 141-159.

Evans, J.D., Schwarz, R.S., Chen, Y.-P., Budge, G., Cornman, R.S., et al. (2013) Standard methodologies for molecular research in Apis mellifera. In Dietemann $\mathrm{V}$, Ellis JD, Neumann P (Eds) The COLOSS BEEBOOK, Volume I: Standard methods for Apis mellifera research. J. Apic. Res., 52(4). doi:10.3896 /IBRA.1.52.4.211

Haddad, N. (2011) Bee losses and Colony Collapse Disorder in the Middle East. Uludag Bee J., 11:(1), 17-24.

Haddad N. (2014) First Detection of Nosema ceranae in Jordan. Eur. Sci. J., 10(35), 91-96.

Haddad, N., Brake, M., Migdadi, H., de Miranda, J.R. (2008) First detection of honey bee viruses in Jordan by RT-PCR. Jordan J. Agric. Sci., 4(3), 242-247. 
Haddad, N, Adjlane NJ, Al-Shagour B, Loucif-Ayad W, ElNiweiri M, et al. (2015) Distribution and variability of deformed wing virus of honeybees (Apis mellifera) in the Middle East and North Africa. Insect Sci. doi:10.1111/1744-12277.
Loucif-Ayad, W., Chefrour, A., Algharibeh, M., Haddad, N. (2013) First detection of deformed wing virus of honeybees in Algeria. Phytoparasitica, 4, 445-447.

Ruttner, F. (1975) African races of honeybee. Proc. Int. Apic. Congr. 25th, Pp. 325-344 